\title{
UJI EFEKTIFITAS AIR PERASAN JERUK NIPIS (CITRUS LAURANTIFOLIA) DAN JERUK LEMON (CITRUS LIMON) TERHADAP PROPIONIBACTERIUM ACNES
}

\author{
Elisabet Tampubolon ${ }^{1}$, Windy Claudia Lubis ${ }^{2}$, Ali Napiah Nasution ${ }^{3}$, Riyani Susan Bt. Hasan ${ }^{4}$ \\ 1,2,Program Studi Pendidikan Dokter, Fakultas Kedokteran, Universitas Prima Indonesia \\ ${ }^{3}$ Kedokteran Tropis, , Fakultas Kedokteran, Universitas Prima Indonesia \\ ${ }^{4}$ Mikrobiologi, , Fakultas Kedokteran, Universitas Prima Indonesia \\ riyanisusan@gmail.com
}

\begin{abstract}
Abstrak
Buah jeruk lemon dan jeruk nipis diketahui punya kandungan geranil asetat, kalsium, vitamin $\mathrm{C}$, serat, dan flavonoid dan sering digunakan untuk menurunkan demam, batuk dan termasuk juga masalah jerawat. Tujuan dilaksanakan penelitian ialah mengetahui aktivitas hambatan dari perasan jeruk nipis dan lemon pada pertumbuhan propionic bacterium acnes. Penelitian ini dilakukan menggunakan desain eksperimental memakai metode dari difusi cakram. Berlandaskan dari data pengujian yang sudah dilakukan pada air peras jeruknipispadaperkembangandariPropionibacterium acnes,25\%(8,83mm), 50\%(12,03mm), 75\%(13,26mm), $100 \%(14,1 \mathrm{~mm})$ dari semua konsentrasi, konsentrasi $100 \%$ memiliki daya hambat yang paling tinggi dan konsentrasi pada jeruk lemon $25 \%(9,93 \mathrm{~mm}), 50 \%(12,46 \mathrm{~mm}), 75 \%(14,83 \mathrm{~mm}), 100 \%(16,4 \mathrm{~mm})$, dari semua konsentrasi, konsentrasi $100 \%$ dan memiliki daya hambat yang paling tinggi. Kontrol positif menggunakan cakram klindamisin dari keseluruhan bahan yang dipakai, control positif dengan klindamisin memiliki aktivitas yang paling tinggi, untuk mengurangi perkembangan propionic bacterium acne yaitu $17 \mathrm{~mm}$. Maka kesimpulannya , bahwa adanya efek dalam menurunkan pertumbuhan dari air perasan jeruk nipis juga jeruk lemon untuk Propionibacterium acnes.
\end{abstract}

Kata kunci : jerawat, perasan jeruk nipis dan lemon, propionic bacterium acnes.

\begin{abstract}
Lime and lemon are known have vitamin C, geranil acetate,calcium,fiber, and flavonoids and often used for fever, cough and including acnes. The research was conducted using an experimental design using the method of disc diffusion. Based on test that has been carried out of lime juice in the development of Propionibacterium acnes $25 \%(8,83 \mathrm{~mm}), 50 \%(12,3 \mathrm{~mm}), 75 \%(13,26 \mathrm{~mm})$ and $100 \%(14,1 \mathrm{~mm})$ of all concentration in lime juice $100 \%$ has the highest resistance and concentracion in lemon $25 \%(9,93 \mathrm{~mm}), 50 \%(12,46 \mathrm{~mm}), 75 \%(14,83 \mathrm{~mm})$, and $100 \%(16,44 \mathrm{~mm})$ of all concentration in lemon juice $100 \&$ has the highest resistance. Positive control using clyndamycin disc of maximum overall height of $17 \mathrm{~mm}$ higher the inhibitory effect on the development of Propionibacterium acnes. So the conclusions, is that there growths inhibition in the juice of lime and lemon of Propionibacterium acnes.
\end{abstract}

Keywords:acnes, lime, lemon juice, Propionic bacterium acnes. 


\section{PENDAHULUAN}

Gangguan pada kulit sering kali muncul, sering dikaitkan dengan kondisi tubuh salah satunya pada saat stres, juga faktor genetik, dan produk kecantikan. Bakteri yang biasa menimbulkan pembengkakan (abses) seperti jerawat, infeksi kulit salah satunya adalah bakteri Propionibacterium acne. ${ }^{5}$

Propionibacteruim acnes ialah bakteri batang gram positif yang membuat inflamasi dikulit (acne) bekerja dengan memecahkan asam lemak dan menghasilakn lipase, sehingga membuat inflamasi pada kulit dan menjadi acne. ${ }^{6}$

Untuk mencegah munculnya acne, yakni memakai jeruk lemon (citrus limon) \& jeruk nipis (citrus aurantifolia) mempunyai kandungan geranil asetat, vitamin C, serat kalsium, tannin, limonoid dan terpeinoid, dan sering dipakai kebanyakan orang dalam hal seperti obat diare,antiinflamasi, dan antibakteri. $^{5}$

\section{METODE}

Desain penelitian yang digunakan adalah eksperimental laboratorium Waktu dan tempat dilakukannya penelitian ini adalah pada Mei hingga Juli 2020 berlokasi di laboratorium Mikrobiologi Fakultas Kedokteran Universitas Prima Indonesia.

Tabung reaksi, Autoclave, spektrofoto-meter, mikropipet, pengukuran waktu, Timbangan, Bunsen, Cakram uji kosong, Alat tulis, Kamera, Cawan petri (petri dish), pinset, Ose, Korek api, Jangka sorong, Tabung Erlenmeyer, merupakan alat-alat yang digunakan dalam penelitian ini dan Biakan Propionobacterium acnes, Media Mueller-Hinton Agar (MHA), perasan air dari jeruk nipis \& jeruk lemon,Alkohol,Spiritus, $\mathrm{NaCl} \quad 0,9 \%$,Cotton swab steril,Aluminium foil,Kertas saring,Tisu merupakan bahan bahan yang di gunakan dalam penelitian ini. ${ }^{3}$

Konsentrasi air perasan jeruk nipis dan jeruk lemon yang dipakai yaitu 25,50,75,dan 100\%. Untuk mendapatkan masing-masing konsentrasi, maka dilakukan dengan metode volume per volume $(\mathrm{v} / \mathrm{v})$ dengan menggunakan bahan pelarut aquadest steril 6

Pembuatan Media Mueller Hinton Agar, Siapkan bubuk media Mueller Hinton Agar.Bubuk media dipindahkan kedalam Erlenmeyer dan dilarutkan dengan aquades sebanyak $200 \mathrm{ml}$. Media dilarutkan dan dipanaskan dengan hotplate. Setelah bubuk media larut dan homogen, Erlenmeyer ditutup dengan aluminium foil berfungsi untuk mencegah terjadinya kontaminasi udara dari luar. ${ }^{2}$
Media disterilisasi dengan autoclave, suhu $121^{\circ} \mathrm{C}$, tunggu 15 menit. Setelahnya, media dituangkan ke petridish atau cawan petri steril secara aseptis sebanyak $15 \mathrm{ml}$. Media didiamkan hingga memadat. Setelah media memadat, petridish dibalik. $^{4}$

Pembuatan suspensi Bakteri Propionibacterium acnes, satu sampai tiga ose koloni Propionibacterium acnes dari biakan murni diambil, larutan $\mathrm{Nacl} 0.9 \% 5 \mathrm{ml}$ suspensikani pada tabung steril.Kekeruhan bakteri dapat diperiksa memakai membandingkan kekeruhan standar 0,5 Mc Farland (setara dengan 1,5 x $108 \mathrm{CFU} / \mathrm{mL}$ ). ${ }^{8}$

Cakram disk kosong disiapkan dan diteteskan $20 \mu \mathrm{l}$ perasan buah jeruk nipis dan jeruk lemon dengan konsentrasi yang telah disiapkan sampai meresap ke cakram disk. Disiapkan suspensi bakteri Propionibacterium acnes.

Disiapkan cotton swab steril dan dicelupkan ke dalam suspensi tersebut. Cotton swab steril diperas dengan cara menekannya pada dinding dalam tabung dan diangkat. Lakukan inokulasi pada media Mueller Hinton Agar (MHA) (goresan dilakukan secara merata hingga tertutupi seluruh permukaan media). ${ }^{1}$

Media yang sudah disuspensi didiamkan selama 15 menit. Cakram disk yang sudah jenuh dengan perasan jeruk nipis dan jeruk lemon ditempelkan pada media bakteri dan sedikit ditekan dengan pinset hingga melekat sempurna. Control (+) dan (-) ditempel di tempat berbeda. Jarak cakram sebisa mungkin berjarak $15 \mathrm{~mm}$ dan cakram disk jangan digeser. Media yang ditempeli dengan cakram disk didiamkan 5 sampai 15 menit. Inkubasikan selama 24 jam dengan $37^{\circ} \mathrm{C}$ dalam posisi terbalik dan akn diukur dengan jangka sorong. ${ }^{7}$

HASIL

Hasil Pengujian Anti Bakteri 


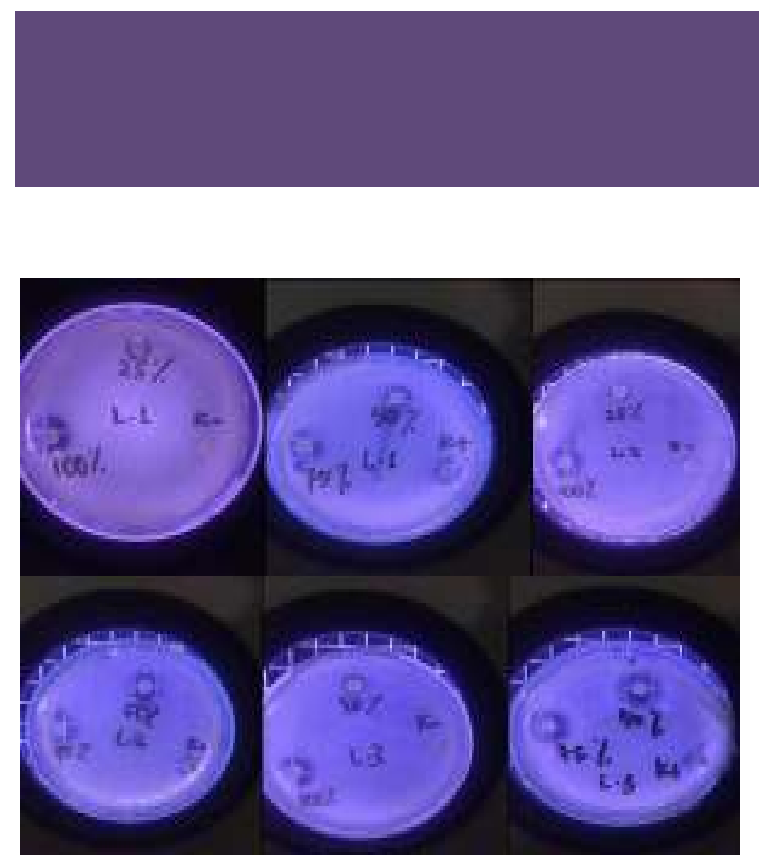

Gambar 1.Zona bening pada bakteri saat sudah diberi perasan jeruk lemon

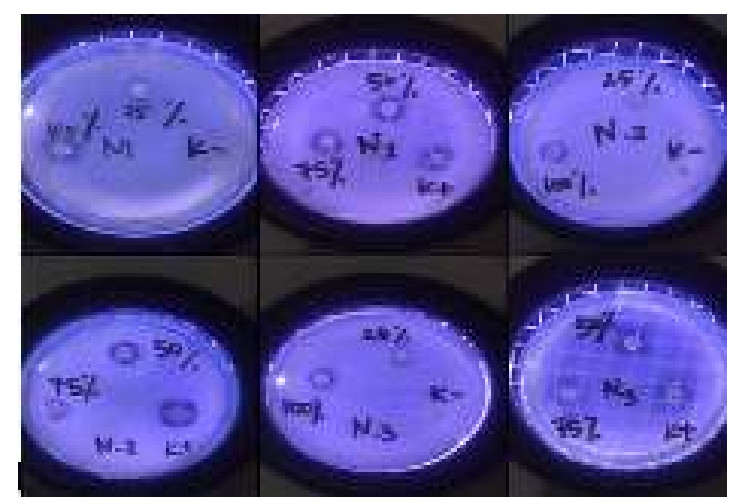

Gambar 2. Zona bening pada bakteri saat sudah diberi perasan jeruk nipis.

Perbandingan Diameter Zona Hambat Ekstrak Perasan Air Jeruk Nipis UntukMengurangi Pertumbuhan Bakteri PropionibacteriumAcnes

Tabel 1.Tabel Pada Bakteri Diberi Air Perasan JerukNipis

\begin{tabular}{cccccc}
\hline No. & Kons. & $\begin{array}{c}\text { D1 } \\
\text { (mm) }\end{array}$ & $\begin{array}{c}\text { D2 } \\
\text { (mm) }\end{array}$ & $\begin{array}{c}\text { D3 } \\
\text { (mm) }\end{array}$ & $\begin{array}{c}\text { Kriteria } \\
\text { Hambatan }\end{array}$ \\
\hline 1 & $25 \%$ & 9,8 & 8,1 & 8,6 & $8,83 \mathrm{~mm}$ \\
\hline 2 & $50 \%$ & 11,7 & 11,2 & 13,2 & $12,03 \mathrm{~mm}$ \\
\hline 3 & $70 \%$ & 13,0 & 11,9 & 14,9 & $13,26 \mathrm{~mm}$ \\
\hline 4 & $100 \%$ & 15,2 & 12,0 & 15,1 & $14,1 \mathrm{~mm}$ \\
\hline
\end{tabular}

JIMKesmas

Jurnal Ilmiah Mahasiswa Kesehatan Masyarakat Vol. 5/No. 4/Oktober 2020; ISSN: 2502-731X

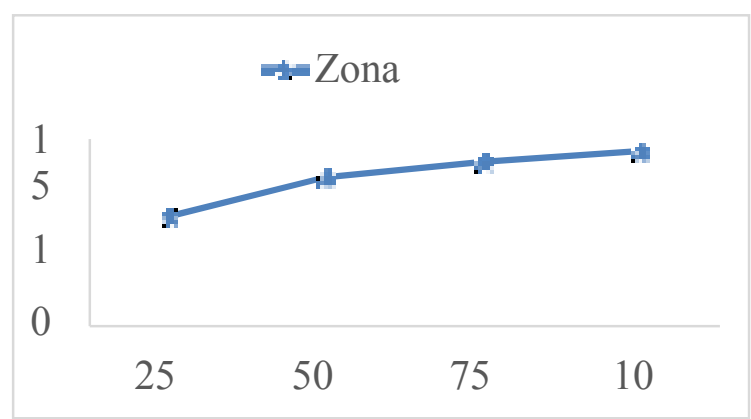

Gambar 3.Grafik Pada Bakteri Diberi Perasan JerukNipis

Dari tabel 1. dan gambar 3. diatas dapat dilihat jika adanya zonna bening yang meningkat kepada bakteri Propioni-bacterium Acnes dari jeruk nipis yang sudah diperas berawal dari volume $25 \%$ $(8,83 \mathrm{~mm}), 50 \%(12,03 \mathrm{~mm}), 75 \% \quad(13,26 \mathrm{~mm})$, dan $100 \%(14.1)$.

Perbandingan Diameter Zona Hambat Ekstrak Air Perasan Jeruk Lemon Dalam Menghambat Pertumbuhan Bakteri PropionibacteriumAcnes

Tabel 2. Tabel Pada Bakteri Diberi Air Perasan Jeruk Lemon

\begin{tabular}{cccccc}
\hline No. & Kons. & $\begin{array}{c}\text { D1 } \\
(\mathbf{m m})\end{array}$ & $\begin{array}{c}\text { D2 } \\
(\mathbf{m m})\end{array}$ & $\begin{array}{c}\text { D3 } \\
(\mathbf{m m})\end{array}$ & $\begin{array}{c}\text { Kriteria } \\
\text { Hambatan }\end{array}$ \\
\hline 1 & $25 \%$ & 10,1 & 9,5 & 10,2 & $9,93 \mathrm{~mm}$ \\
\hline 2 & $50 \%$ & 11,7 & 12,5 & 13,2 & $12,46 \mathrm{~mm}$ \\
\hline 3 & $70 \%$ & 14,9 & 14,7 & 14,9 & $14,83 \mathrm{~mm}$ \\
\hline 4 & $100 \%$ & 16,4 & 15,8 & 17,0 & $16,4 \mathrm{~mm}$ \\
\hline
\end{tabular}

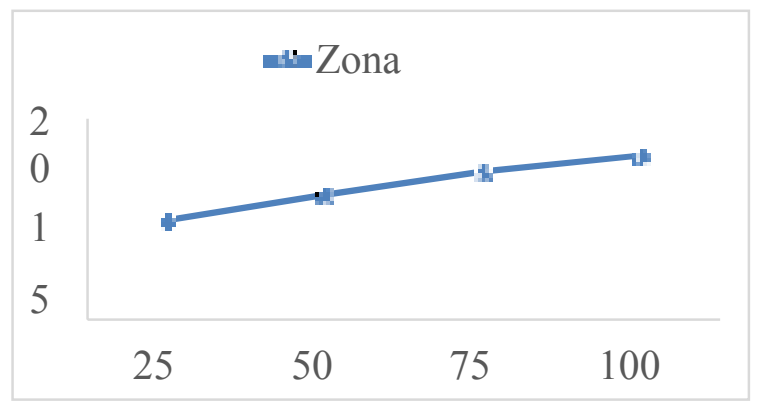

Gambar 4. Grafik Pada Bakteri Diberi Perasan Jeruk Lemon

Dari tabel 2. Dan gambar 4.diatas dapat dilihatbahwa peningkatanaktivitashambat pada bakteri Propionibacterium Acnes dari air perasan jeruk lemon dengan konsentrasi $25 \%(9,93 \mathrm{~mm}), 50 \%$ $(12,46 \mathrm{~mm}), 75 \%(14,83 \mathrm{~mm})$, dan $100 \%$ (16.4). 
Jurnal Ilmiah Mahasiswa Kesehatan Masyarakat Vol. 5/No. 4/Oktober 2020; ISSN: 2502-731X

\section{Konsentrasi Hambat Minimum (KHM)}

Ini dibuat setelah mendapatakan volume paling sedikit pada pengujian yang telah dilakukan dalam menguji bakteri dengan air perasan jeruk nipis dan jeruk lemon supaya tahu akan kemampuannya dalam menghambat pertumbuhan bakteri. Konsentrasi air perasan jeruk nipis dan jeruk lemon yangg digunakan yaitu $25 \%$ dan $50 \%$. Hasilnya setelah inkubasi selama 24 jam.

Tabel 3. Tabel KHM

\begin{tabular}{cccl}
\hline No. & $\begin{array}{c}\text { Kons. } \\
\text { JN }\end{array}$ & $\begin{array}{c}\text { Kons. } \\
\text { JL }\end{array}$ & \multicolumn{1}{c}{ Ket } \\
\cline { 1 - 3 } 1 & $25 \%$ & $25 \%$ & $\begin{array}{l}\text { Terdapat } \\
\text { zonahambatdenganter } \\
\text { bentuknyazona bening. }\end{array}$ \\
\hline 2 & $50 \%$ & $50 \%$ & \\
\hline
\end{tabular}

KHM (Konsentrasi Hambat Minimum) yang digunakan yaitu $25 \%$ dan memiliki hambatan pada jeruk nipis $(8,83 \mathrm{~mm})$ dan jeruk lemon $(9,93)$.

\section{Konsentrasi Bunuh Minimum (KBM)}

Tujuan dari pengujian ini, untuk mengetahui kemampuan besaran volume antibakteri yang mampu membunuh bakteri dengan menggunakan konsentrasi terendah yaitu $25 \%$ dan $50 \%$ pada jeruk lemon dan jeruk nipis dalam perasannya dalam uji KHM dan tidak ditumbuhi bakteri (zona bening).

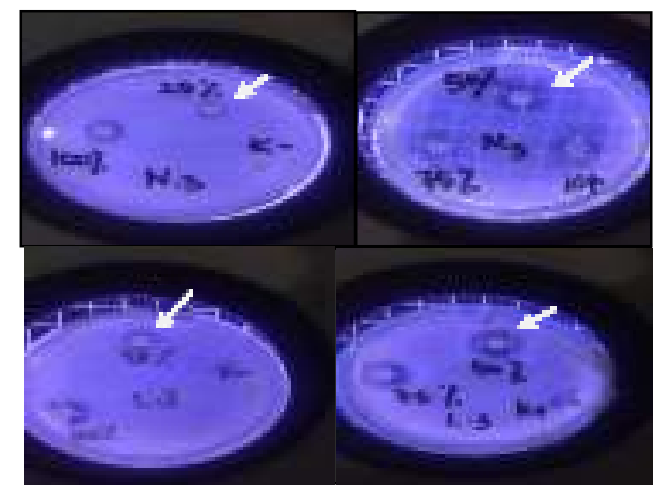

Gambar 5. Gambar KBM pada air perasan dengankonsentrasi $25 \%$ dan $50 \%$ pada perlakuanketiga.

\begin{tabular}{|c|c|c|}
\hline Kons. & Interpretasi JN & Interpretasi JL \\
\hline $25 \%$ & $\begin{array}{l}\text { Terdapat zonabening } \\
\text { dengandiameter } 8,6 \mathrm{~mm}\end{array}$ & $\begin{array}{l}\text { Terdapat zona } \\
\text { bening } \\
\text { dengandiameter } \\
10,2 \mathrm{~mm}\end{array}$ \\
\hline $50 \%$ & $\begin{array}{l}\text { Terdapat zona bening } \\
\text { dengan diameter } 13,2 \\
\mathrm{~mm}\end{array}$ & $\begin{array}{l}\text { Terdapat zona } \\
\text { bening } \\
\text { dengandiameter } \\
13,2 \mathrm{~mm}\end{array}$ \\
\hline
\end{tabular}

\section{Uji Oneway Anova}

Dari hasil uji statistika yang dilakukan pada kedua ekstrak menggunakan uji oneway anova didapati nilai signifikannya $=0,000$, hal ini mengartikan bahwa nilai signifikansi $<\alpha=0,05$, yaitu didapat dengan volume yang berbeda-beda pada jeruk lemon maupun jeruk nipis, perasannya dengan memiliki pengaruh kepada pertumbuhan bakteri Propionibacterium Acnes. Sehingga pengujian hipotesa dapat disimpulkan bahwa ho ditolak dan ha diterima "ada pengaruh pemberian air perasan jeruk lemon dan jeruk nipis terhadap pertumbuhan Bakteri Propionibacterium Acnes.

\section{DISKUSI}

Aktifitas pada air perasan jeruk nipis bisa dilihat yakni daya hambat yang berhasil diukur, dimana sudah terwujud di Media Mueller- Hinton Agare, dari hal itu diperoleh yakni terjadi hambatan pada air jeruk nipis pada Propionibacterium Acnes.

Dari hasil penelitian, didapati bahwa diameterzonna bening (hambat) yang berbeda-beda, hal ini dikarnakan perbedaan konsentrasi dari perasan air jeruk nipis. Semakin tinggi volume perasan jeruk nipis yang di dapat yakni kemampuan penghambatan dengan diukur diameter beningnya maka yang terbentuk semakin besar.

Besarnya volume yang didapat mempunyai bahan aktif dan memilki efek antibakteri dan pada kemampuannya mengurangi perkembangan bakteri semakin banyak. Dalam hal ini, memiliki hasil yang mirip seperti uji efektifitas jeruk nipis peras dengan Escherichia coli, yakni dilihat bahwa adanya aktivitas hambatan terhadap bakteri, dengan konsentrasi 5 , $12,5,25,50,75$, dan $100 \%$.dan juga hasil yang didapati 7,$15 ; 9,20 ; 11,25 ; 12,50 ; 14,10$ dan 16,90 (dalam mm). ${ }^{10}$

Aktifitas oleh air perasan jeruk lemon, yakni dilihat diameter bening Media Mueller Hinton Agare. Maka, boleh disebut perasan jeruk nipis yakni 
menurunkan perkembangan bakteri Propionibacterium acnes. Dilihat dari berbagai ukuran yang berbeda-beda dikarenakan volume perasan dari jeruk lemon. Peningkatan volume perasan jeruk lemon membuat aktivitas yang ditimbulkan dengan mengukur diammeter zonna bening yang terbentuk semakin besar.

Olehnya diketahui bahwa dari besarnya perasan jeruk lemon, yakni berefeknya dengan banyaknya volume jeruk lemon semakin bertambah besar pula dalam hambat bakteri.Pada penelitian uji aktifitas pertumbuhan Propionibacterium acne memakai lemondan madu hutan dalam menghambat Acnes, di dapat hambatan pada bakteri Propionibacterium Acnes tetapi dengan beda konsentrasinya dan di dapat gambaran bening sebesar $0,3 \mathrm{~cm}, 0,35 \mathrm{~mm}, 0,41 \mathrm{~cm}, 0,51 \mathrm{~cm}$, dan $0,78 \mathrm{~cm} .{ }^{9}$

Berlandaskan data diatas menunjukkan bahwa didapat efek dari jeruk nipis yang telah diperas terhadap pertumbuhan bakteri Propionibacterium Acnes dari konsentrasi $25 \%(8,83 \mathrm{~mm}), 50 \%(12,03 \mathrm{~mm}), 75 \%(13,26 \mathrm{~mm})$, dan $100 \%(14.1 \mathrm{~mm}){ }^{9}$

\section{SIMPULAN}

Berlandaskan data diatas menunjukkan bahwa didapat effect dari jeruk nipis yang telah diperas terhadap pertumbuhan bakteri Propionibacterium Acnes dari konsentrasi 25\%(8,83mm), $50 \%(12,03 \mathrm{~mm}), 75 \%(13,26 \mathrm{~mm})$, dan100\%(14.1).

Berdasarkan hasil diatas menunjukkan bahwa terhadap pengaruh perasan air dari jeruk lemon terhadap pertumbuhann bakteri Propionibacterium Acnes dari konsentrasi 25\%(9,93mm), $50 \%(12,46 \mathrm{~mm}), 75 \%(14,83 \mathrm{~mm})$, dan100\%(16.4).

KHM (Konsentrasi Hambat Minimum) jeruk nipis dan jeruk lemon dengan memakai air perasannya, digunakan yaitu $25 \%$ dengan memiliki hambatan yang dihasilkan jeruk nipis $(8,83 \mathrm{~mm})$ dan jeruk lemon (9,93mm).

KBM (Konsentrasi Bunuh Minimum) jeruk nipis yang telah diperas dan jeruk lemon digunakan yaitu $25 \%$ dengan memiliki hambatan yang dihasilkan jeruk nipis $(8,83 \mathrm{~mm})$ dan jeruk lemon(10,2mm).

Berdasarkan hasil diatas menunjukkan bahwa air perasan jeruk lemon lebih baik ketimbang air perasan jeruk nipis dalam mengurang tumbuh bakteri Propionibacterium Acnes. Dikarenakan volume dari air jeruk lemon dengan peningkatan diameter zonna bening bakteri Propionibacterium
Acnes sebesar 96,1\%, sedangkan jeruk nipis, didapati bertambah aktivitas hambat bakteri Propionibacterium Acnes sebanyak 69,1\%.

\section{SARAN}

1. Disarankan kepada penelitian berikutnya lebih berhati-hati dalam membiakan bakteri. Disaranakan untuk penelitian berikutnya untuk mencoba menganti tingkat konsentrasi airperasan.

2. Perlu untuk dilakukannya penelitian lebih lanjut untuk melihat efektifitas jeruk nipis dan lemon dalam menghambat bakterilain.

3. Disarankan berhati-hati dalam menjaga alat tetap steril.

\section{DAFTAR PUSTAKA}

1. Lajira MM, Ehrich Lister IN. Uji Antibakteri Ekstrak Buah Takokak (Solanum Torvum Swartz) Terhadap Pertumbuhan Bakteri Propionibacterium Acnes. BIOLINK (Jurnal Biol Lingkung Ind Kesehatan). 2019;6(1):73.

2. Mardiah M. Uji ResistensiStaphylococcus aureusTerhadap Antibiotik, Amoxillin, Tetracyclin dan Propolis. J Ilmu Alam dan Lingkung. 2017;8(2):1-6.

3. Hartin E, Rini CS. Efektivitas Jeruk Lemon ( Citrus limon Linn ) terhadap Staphylococcus epidermidis. 2019;2(1):6-9.

4. Pastor NMZ. Uji efektivitas antibakteri ekstrak rimpang kunyit (curcuma domestica val.) Terhadap pertumbuhan Propionibacterium acnes SECARA IN VITRO. 2019;23(3):2019.

5. Saputra O, Anggraini N. Khasiat Belimbing Wuluh ( Averrhoa bilimbi L .) Terhadap Penyembuhan Acne Vulgaris. Majority. 2016;5(1):76-80.

6. Surya Amal NKSAE. Uji Efektivitas Air Perasan Jeruk Nipis (Citrus Aurantifolia) Dan Madu Randu Dalam Menghambat Pertumbuhan Bakteri Propionibacterium acnes. Pharm J Islam Pharm. 2018;2(2):17.

7. Trisuci HD, Soewardi DS, Khu A, Indonesia UP, Indonesia UP. Uji Aktivitas Antibakteri Air Perasan Buah Timun ( Cucumis Sativus ) Terhadap Pertumbuhan Bakteri Propionibacterium. 2020;3(1):14-8.

8. Ilmiah J, Keguruan M, Unsyiah IP. Uji aktivitas kombinasi perasan jeruk nipis (citrus aurantifolia swingle), belimbing wuluh (averrhoa bilimbi I.) Dan bawang putih (allium sativum I.) Terhadap penghambatAN PERTUMBUHAN BAKTERI Propionibacterium acnes SECARA IN VITRO. 
2020;5(1):45-56.

9. Indriani, Yeni; mulqie, lanny; hazar siti. Uji aktivitas antibakteri air perasan buah jeruk lemon (citrus limon (I.) Osbeck) dan madu hutan terhadap propionibacterium acnes. 2015;

10. Eliana K, Dewi K, Habibah N, Mastra N. Uji daya hambat berbagai konsentrasi perasan jeruk lemon terhadap bakteri propionibacterium acnes kadek. 2015;14(6):86-93. 